\title{
PEDAGOGY
}

\section{Training of future workers of the social sphere for implementation of social and pedagogical support of the minors exonerated with probation: result of experimental introduction of pedagogical conditions}

\author{
V. V. Angolenko \\ Graduate student of the State higher educational institution "Donbass State Pedagogical University" (Sloviansk) \\ Paper received 06.06.18; Accepted for publication 14.06.18.
}

\author{
https://doi.org/10.31174/SEND-PP2018-170VI70-01
}

\begin{abstract}
In article questions of training of future workers of the social sphere for implementation of social and pedagogical support of the minors exonerated with probation have been considered: result of experimental introduction of pedagogical conditions; results of experimental introduction of pedagogical conditions of training of future workers of the social sphere for implementation of social and pedagogical support of the minors exonerated with probation have been proved.
\end{abstract}

Keywords: training of workers of the social sphere, minor offenders, penal system, probation service, pedagogical conditions.

Problem statement. Today in the conditions of intensification of the social conflicts in Ukraine social work is understood first of all as the practice-oriented branch of knowledge aimed at rendering the social help and support of people which belong to group of "social risk". At the same time, inevitably there is the whole complex of the problems connected with need of changes in training of future workers of the social sphere connected, in particular, with reforming of penal system and changes in standard and regulatory framework of the state.

Analysis of the last researches and publications. The Ukrainian scientists I. Bogatyrev, M. Evtukh, E. Karaman, V. Krivusha, T. Kushnareva, V. Sinev, D. Yagunov, I. Yakovets and others in their works have mentioned psychology and pedagogical aspects of work with various categories of offenders including juvenile that are convicted to the punishments which aren't connected with imprisonment, they have paid certain attention to training of future workers of the social sphere; I. Zvereva, A. Kapskaya, L. Mishchik, S. Harchenko have proved professional appointment of the modern social worker; V. Danilchenko, L. Kovchin, N. Lavrichenko, L. Sushchenko, L. Horuzhaya, I. Tsybulina have defined an originality of various directions of social and pedagogical activity of the expert of the social sphere in particular, human rights; T. Alekseenko, I. Bogdanova, S. Boltivets, Yu. Lysenko, O. Rasskazova, I. Trubavina, Yu. Chernetskaya and others have disclosed specifics of activity of the social teacher in various institutions. At the same time, the analysis of scientific works has shown that the questions connected with training of future workers of the social sphere for implementation of social and pedagogical support of the minors exonerated with probation are remained inadequately treated.

Therefore the purpose of the article is the justification of results of experimental introduction of pedagogical conditions of training of future workers of the social sphere for implementation of social and pedagogical support of the minors exonerated with probation.

Statement of basic materials. Training of future workers of the social sphere for professional activity, in particular to implementation of social and pedagogical support of the minors exonerated with probation demands from the expert of social work: knowledge of a technique of interaction and ability to make a psychological contact with minor offenders and their families taking into account gender features of the clients; to be guided by legal and regulatory base of respect for the rights of minors with illegal behavior; to rely on modern approaches of social work in the organization of implementation of social and pedagogical support of the minors exonerated with probation and so forth.

This all show a clear need for revision of the existing training programs in the direction 231 Social work and disciplines which teaching is directed to formation of knowledge and abilities of future worker of the social sphere for implementation of social and pedagogical support of the minors exonerated with probation. Therefore we have carried out the theoratical and methodological analysis of studying of experience of training of future workers of the social sphere for implementation of the professional functions, in particular for implementation of social and pedagogical support of the minors exonerated with probation and the analysis of educational programs of training of bachelors of social work in the municipal institution "Kharkiv Humanitarian and Pedagogical Academy" of the Kharkiv regional council, the Luhansk national university of Taras Shevchenko (Starobelsk), Umansky state pedagogical university of Pavel Tychina and Sumy state pedagogical university of A.S. Makarenko.

The analysis which has been carried out by us revealed that programs of subject matters provide superficial and almost deprived by a contextual component acquaintance with information allowing to create the necessary level of knowledge of future workers of the social sphere within a cycle of professionally focused disciplines. We have seen the solution of this problem in development and introduction in educational process of pedagogical conditions of training of workers of the social sphere for implementation of social and pedagogical support of the minors exonerated with probation, namely: integration of subject matters, for the direction of their educational potential on formation and development of complete system of knowledge and skills necessary for future worker of the social sphere at implementation of social and pedagogical 
support of the minors exonerated with probation; activization of practical training of future workers of the social sphere on the basis of social partnership with the Center of gender culture, Northeast interregional directorate concerning execution of criminal penalties and a probation of the Ministry of Justice; use in educational process of future workers of the social sphere for implementation of social and pedagogical support of the minors exonerated with probation of contextual technologies of training (risk assessment of commission of repeated offense, directing of a case, case methods, etc.).

Notice that, whereas the process of training of future workers of the social sphere for implementation of social and pedagogical support of the minors exonerated with probation happens in national educational standard and it is complete and system that has made impossible the local introduction of each of the pedagogical conditions proved by us, their realization during the experiment has happened in a complex and gradually.

At the first organizational stage it has been carried out training of all agents of pedagogical process for realization of pedagogical conditions, development and enrichment of substantial and methodical providing, forecasting of achievements. At this stage the result of realization of the specified conditions has been the filling of contents of the integrated working programs with subjects for formation and development of complete system of knowledge, skills necessary for future worker of the social sphere in the course of resocialization of minor offenders and introduction of elective courses "Bases of social work in a probation service" and "Social work in the conditions of penal system".

In particular, in contents of the training program "Introduction to specialty" has been itemized the subject "Minor Offenders as Objects of Social Work" which provides consideration of the following questions: regulatory framework of social work with minor offenders; interrelation of social work and penitentiary pedagogics, prevention of illegal behavior of minors taking into account gender features.

Contents of the training program "General, age and pedagogical psychology" has been complemented with the subject "Psychological Features of Minors with Deviant Behaviour" that has to take up the following questions: analysis of the reasons of deviant behavior of minors; deviant behavior, norm and pathology, sexual deviations of teenagers.

So, in contents of the training program of "The concept of social education in the history of a pedagogical thought" has been complemented with the subject "Social Education of Children with Illegal Behaviour" that has opened a question: adverse conditions of socialization of children as social and pedagogical problem; methods of social work with minor offenders.

In contents of the training program of "A basis of social and pedagogical diagnostics" has been itemized the subject "Social and Pedagogical Diagnostics in Probation Service for Convicts with Different Types of Punishment" that has opened a question: means of establishment of the level of development of social knowledge and skills of minor offenders.

The training program "Psychology and pedagogical bases of interpersonal communication" has been added to the subject "Social and Pedagogical Means of Formation of Communicative Interaction with Minor Offenders" that has opened a question: forms, methods and technics of communicative interaction of the expert of social work with minor offenders.

The training program of "A basis of a social and pedagogical training" is complemented with the subject "Use of Innovative Methods in the course of Resocialization of the Exonerated Minors" that has opened questions, namely: application a forum theater, a case management, a flash mob in the course of social and pedagogical support and resocialization of minor offenders.

Content of a subject matter "Bases of social and legal protection of the childhood. A technique of legal education and prevention of offenses" has been added to such Subject "Legal and Regulatory Framework of the Rights of the Child Who Is in the Conflict with the Law" and such questions have been opened: legal and regulatory framework of social work with children with illegal behavior; participation of law enforcement agencies, educational and fostering institutions, human rights and public organizations in resocialization of minor offenders; the latest forms and methods of preventive maintenance with the children who are in the conflict with the law.

Correction of content of a subject matter "Models and technologies of social work in the countries of the world" has been carried out due to expansion of questions of the subject "International Experience of Social Work with Minor Offenders", namely: mediative practices in work with minor offenders; recovery practices in work with the exonerated minors; programs of a probation concerning minors.

The content of a subject matter "A technique of gender education" has been complemented with the subject "Gender Sensitive Approach in Work with Minor Offenders", by means of questions: essence of a concept gendersensitive approach; use of resocialization technics taking into account gender-sensitive approach.

Introduction of elective courses "Bases of social work in probation service" and "Social work in the conditions of penal system" was intended to develop in students interest to social works in probation service; to acquaint with essence of the common theoretical problems and content of social work in probation service; to create conceptualization about the international and domestic experience of formation and development of social work in penal system; to study modern approaches to justification of activities of workers of the social sphere in penal system, in particular with application gender-sensitive approach; to acquaint students with methods and technologies of social work in the course of restorative justice and mediation, a probation and alternative forms of punishment. Each of subjects of elective courses have reflected certain tasks in formation of knowledge of future workers of the social sphere, in particular for implementation of social and pedagogical support of the minors exonerated with probation.

It should be noted that carrying out of lectures of elective courses "Bases of social work in probation service" and "Social work in the conditions of penal system" has happened with application of contextual methods and technologies of training that has contributed to the development of creative thinking in students, to formation of 
abilities to define own position and to use the acquired psychological and pedagogical and social and pedagogical knowledge in various educational and professional conditions.

Considerable potential in formation of the positive relation to interaction with minor offenders has involvement of students to volunteer activity. Therefore a special complex out-of-class form of work was "The gender open university: training of workers of social and legal spheres - "School of volunteering" [1], realized together with social partners: Center of gender culture, Northeast interregional directorate concerning execution of criminal penalties and a probation of the Ministry of Justice and teachers of department of social work and social pedagogics of municipal institution "Kharkiv Humanitarian and Pedagogical Academy" of the Kharkiv regional council.

The purpose of the project was to prepare and increase the level of gender competence, culture and ensuring gender education in future volunteers of a probation. We will notice that during the lectures "The gender open university: training of workers of social and legal spheres - "School of volunteering" the integration of pedagogical knowledge of the specified problematics has happened; moderators have applied contextual methods and forms of education that has allowed future workers of the social sphere to take active part during training and to approach real professional actions and the most important that they have seen possibilities of social partnership in effect.

With students of control and experimental group researches for the purpose of establishment of level of training of future workers of the social sphere for implementation of social and pedagogical support of the minors exonerated with probation have been conducted by three criteria:

- the cognitive component characterizes the theoretical knowledge gained in the course of mastering a profession from fundamental concepts in modern theories and concepts of social work. The cognitive component assumes students' acquirement of knowledge on the phenomena of deviant behavior, social disadaptation and also knowledge of the reasons, signs, characteristics, offenses; knowledge of norms and deviations in physical, mental, social, intellectual development of the minor offender and so forth.

Besides, the cognitive component of professional competence of the expert contains knowledge of conditions, directions, methods of the social and pedagogical help to the minor offenders exonerated with probation; knowledge and abilities to analyze relationship of the teenager and the environment, to define the nature of influence of this environment; knowledge of acts in the field of social protection of the minors exonerated with probation and understanding of need of constant control of the legislation which changes; mastering by students studying in direction "Social Work" of the system of the scientific and practical and special knowledge necessary for business communication without a conflict with workers and clients of social work; understanding of a role of professional training in practical activities, on the one hand, for achievement of the high level of professionalism, and on the other hand - for the solution of specific social problems of clients with which future worker of the social sphere works [2];

- the motivational component acts in the form of set of subjective indicators of activity. These include requirements, motives, interests, directives, valuable orientations, orientation of the personality, ideals, etc. The motivational and valuable component includes presence in future worker of the social sphere of steady interest in obtaining additional knowledge, abilities and practical experience of social and pedagogical support of the minor offenders exonerated with probation. This component provides formation by student of directives for interaction with the minor offenders exonerated with probation and their parents; stability of valuable orientations of the personality, orientation in professional activity to professional ethical requirements and so forth. Nevertheless, professional training needs to be directed in such a way as to convert natural needs for achievement of success into professional motivation for solution of social problems of minors. The components stated above are an important component of estimate of professional competence of future workers of the social sphere.

- the pragmatist and practical component is characterized by formation by future experts of the social and pedagogical abilities necessary for work with minor offenders. Future worker of the social sphere must be able to develop and to effectively apply the social technologies considering features of a modern combination of gender equality and specifics of sociocultural development of the minor for ensuring his social health.

Notice that in control group students have studied on the basis of traditional technologies of training, and in experimental group the described pedagogical conditions mentioned above have been introduced. After carrying out an experiment it has been realized control pedagogical diagnostics with use of the same methods of a research again, and during the ascertaining experiment. Efficiency of application of reasonable pedagogical conditions of training of future workers of the social sphere for implementation of social and pedagogical support of the minors exonerated with probation has been checked by means of similar indicators and criteria (tab. 1)

Table 1 Results of the comparative analysis

\begin{tabular}{|c|c|c|c|c|c|c|}
\hline \multirow{2}{*}{ Levels } & \multicolumn{7}{|c|}{ Criteria } \\
\cline { 2 - 7 } & motivational & \multicolumn{2}{c|}{ cognitive } & pragmatist and practical \\
\cline { 2 - 7 } & Before & After & Before & After & Before & After \\
\hline \multicolumn{7}{|c|}{ Control Group } \\
\hline critical & 54.3 & 42.2 & 37.7 & 29.5 & 43.9 & 33.4 \\
\hline reproductive & 38.7 & 43.9 & 42.6 & 46.1 & 48.3 & 52.7 \\
\hline productive & 7 & 13,9 & 19.7 & 24.4 & 7.8 & 13.9 \\
\hline \multicolumn{7}{|c|}{ Experimental Group } \\
\hline critical & 46 & 24 & 40 & 24 & 44 & 22 \\
\hline reproductive & 45 & 54 & 41 & 46 & 42 & 55 \\
\hline productive & 9 & 22 & 19 & 30 & 14 & 23 \\
\hline
\end{tabular}


Note that average data of levels of training of future workers of the social sphere for implementation of social and pedagogical support of the minors exonerated with probation in experimental group an increase in productive level has been increased by $11 \%$; reproductive level of training of future workers of the social sphere - by $8.7 \%$, critical level has been reduced by $20 \%$.

Analyzing results of control group we will notice that the productive level of training of future workers of the social sphere for implementation of social and pedagogical support of the minors exonerated with probation has been increased by $5.9 \%$, reproductive level of training by $4.4 \%$ while an indicator of critical level of training of future workers of the social sphere has been lowered by $10.3 \%$.

Conclusions and prospects of further scientific research in this direction. Ways of realization of the specified pedagogical conditions are shown in article and the efficiency of their introduction in teaching and educational process has been confirmed that has allowed to provide training of future workers of the social sphere for implementation of social and pedagogical support of the minors exonerated with probation and statistically significantly to increase its level in experimental group in comparison with control group. Techniques of training of future workers of the social sphere for work with minor offenders are the direction of further researches.

\section{REFERENCES}

1. Angolenko V.V., Beloliptseva E.V., Groshova E.V., Dyomina Yu.V., Isaeva T.A., Lysenko Yu.O., Rasskazova O.I., Preobrazhenskiy V.M., Tkachenko M.E., Chernetskaya Yu.I., Tsybulina I.V. Gender-sensitive approach in work with vulnerable segments of the population in the social and legal sphere: educational and methodical grant. / Made by Angolenko V.V., Beloliptseva E.V., Groshova O.V., Dyomina Yu.V., Isaeva T.A., Lysenko Yu.O., Rasskazova O.I.,
Preobrazhenskaya V.M., Tkachenko M.E., Chernetskaya Yu.I., Tsybulina I.V.; under the general edition of T.V. Otroshko. - K.: KSPA, 2017. -78 p.

2. Zimnyaya I.A. Competency-based approach: what its place in the system of approaches to education problems / I.A. Zimnyaya//the Higher education today. - 2006. - No. 8. - P. 20 26.

Подготовка будущих работников социальной сферы к осуществлению социально-педагогического сопровождения несовершеннолетних, освобожденных от отбывания наказания с испытанием: результат экспериментального внедрения педагогических условий

\section{В. В. Анголенко}

Аннотация. В статье рассмотрены вопросы подготовки будущих работников социальной сферы к осуществлению социально-педагогического сопровождения несовершеннолетних, освобожденных от отбывания наказания с испытанием: результат экспериментального внедрения педагогических условий; обосновании результаты экспериментального внедрения педагогических условий подготовки будущих работников социальной сферы к осуществлению социально-педагогического сопровождения несовершеннолетних, освобожденных от отбывания наказания с испытанием.

Ключевые слова: подготовка работников социальной сферы, несовершеннолетние правонарушители, пенитенциарная система, служба пробации, педагогические условия. 